\title{
Nocturnal Foraging by Buff-striped Keelbacks, Amphiesma stolatum (Linnaeus 1758) (Reptilia: Squamata: Natricidae)
}

\author{
Arpita Dutta ${ }^{1}$, Subhadeep Chowdhury ${ }^{2}$, and Anirban Chaudhuri ${ }^{3}$ \\ ${ }^{1} 1 / 211$, Jodhpur Park, Kolkata, West Bengal, India (arpi.dut83@gmail.com) \\ ${ }^{2}$ Krishnachak, Dhurkhali, Howrah, West Bengal, India (isuvodeep@gmail.com) \\ 36/7, Nature Mates, Bijoygarh, Jadavpur, Kolkata, West Bengal, India (abchaudhuri@gmail.com)
}

$\mathrm{T}$ he Buff-striped Keelback, Amphiesma stolatum (Linnaeus 1758 ), is a diurnally active snake with an extensive distribution in India and throughout much of southeastern Asia (Das 2002; Whitaker and Captain 2008). It exploits various natural and artificial habitats that include paddy fields, ponds, thick grass, bushes, gardens, and lowland forests, usually in the vicinity of water (Das 2002; Whitaker and Captain 2008). These snakes have a diverse diet. Young are known to feed on insects and tadpoles. Adults prey on fishes, anurans, lizards, rodents, and birds, as well as snails and other small invertebrates, including even scorpions (Das 2002; Khan 2002;
Whitaker and Captain 2008; Srinivsaulu et al. 2014). Ghosh and Chaudhuri (2015) also recorded scavenging behavior. Dissanayake and Wellappuliarachchi (2016) reported nocturnal predation by $A$. stolatum in Sri Lanka. Here we report a second instance of nocturnal feeding from Meghauli Serai, Chitwan, Nepal $\left(27.569561^{\circ} \mathrm{N}, 84.201907^{\circ} \mathrm{E}\right.$; elevation 149 $\mathrm{m}$ asl).

At 2029 h on 16 July 2017, we encountered a juvenile A. stolatum holding a small frog (Fejervarya sp.) on a gravel path (Fig. 1) with Elephant Grass (Typha elephantina) on both sides. The snake had started swallowing the frog from

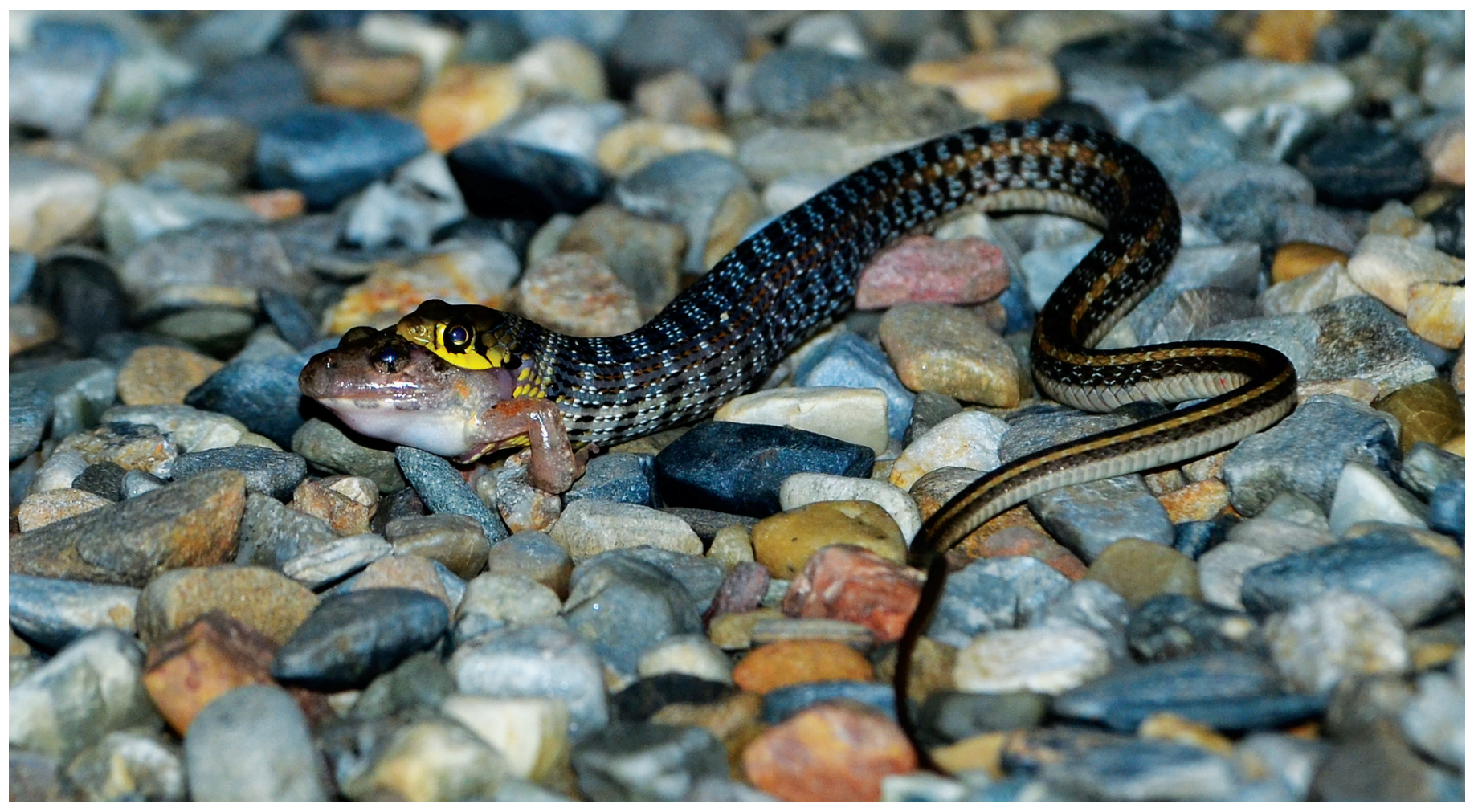

Fig. 1. A juvenile Buff-striped Keelback (Amphiesma stolatum) taking a small frog (Fejervarya sp.) at night. Photograph by Arpita Dutta. 
behind. After about 10 min of observation, it moved into a bush with the frog in its mouth and finished swallowing it. Total time taken to devour the frog was about $17 \mathrm{~min}$. The previous report of nocturnal foraging by Dissanayake and Wellappuliarachchi (2016) at the Mihintale Sanctuary, North Central Province, Sri Lanka involved an A. stolatum feeding on an Indian Burrowing Frog (Sphaerotheca breviceps). Also, at $1900 \mathrm{~h}$ on 20 April 2013, after an evening rain, AC witnessed an adult $A$. stolatum foraging near a marshland pond in Joka, Kolkata, West Bengal, India $\left(22.450721^{\circ} \mathrm{N}\right.$, $80.309635^{\circ} \mathrm{E}$; elevation $4.5 \mathrm{~m}$ asl). That snake was chasing a small Indian Toad (Duttaphrynus melanostictus), but failed to catch it. Hot, humid weather was a common factor in all of these observations.

DeGregorio et al. (2014) demonstrated that Eastern Ratsnakes (Elaphe obsoleta) can switch between diurnal and nocturnal activity. Snakes became more active when the temperature was optimal, regardless of whether it was light or dark. Sperry et al. (2013) noted that E. obsoleta is capable of altering activity patterns in response to short-term proximate cues (temperature and light), shifting in the wild from diurnal to nocturnal behavior over periods of weeks or months. Although our observations are anecdotal, we suggest that $A$. stolatum might engage in similar activity shifts. In humid conditions, when temperatures are optimal and amphibian prey is abundant, these mostly diurnal snakes readily extend foraging behavior into the night.

\section{Acknowledgement}

We thank Roshan Sapkota for his help in the field and Jayaditya Purkayastha for his comments on an earlier draft of this manuscript.

\section{Literature Cited}

Das, I. 2002. A Photographic Guide to Snakes and Other Reptiles of India. New Holland Publishers, Ltd., London, UK.

DeGregorio, B.A., J.H. Sperry, D.P. Valente, and P.J. Weatherhead. 2014. Facultative nocturnal behaviour in snakes: Experimental examination of why and how with Ratsnakes (Elaphe obsoleta) and Racers (Coluber constrictor). Canadian Journal of Zoology 92: 229-237.

Dissanayake, D.S.B. and S. Wellappuliarachchi. 2016. Amphiesma stolatum (Buffstriped Keelback) Diet. Herpetological Review 47: 307.

Ghosh, A. and A. Chaudhuri. 2015. Amphiesma stolata (Buff-striped Keelback). Diet/scavenging. Herpetological Review 46: 442.

Khan, M.S., 2002. A Guide to the Snakes of Pakistan. Edition Chimaira, Frankfurt am Main, Germany.

Sperry, J.H., M.P. Ward, and P.J. Weatherhead. 2013. Effects of temperature, moon phase, and prey on nocturnal activity in ratsnakes: An automated telemetry study. Journal of Herpetology 47: 105-111.

Srinivsaulu, C., B. Srinivasulu, and S. Molur (compilers). 2014. The Status and Distribution of Reptiles in the Western Ghats, India. Conservation Assessment and Management Plan (CAMP). Wildlife Information Liaision Development Society, Coimbatore, Tamil Nadu, India.

Whitaker, R. and Captain, A. 2008. Snakes of India, The Field Guide. Draco Books, Chennai, India. 